\title{
Using file-cases to introduce the Economics of Agricultural Competition Policy
}

\author{
Ana Felis \\ Miguel Cuerdo Mir \\ Universidad Rey Juan Carlos
}

\begin{abstract}
Agriculture is a key and sensitive issue in Europe, but limits between Common Agricultural Policy $(C A P)$ and antitrust policies are a grey area. This paper evaluates the boundaries amongst competition policy and CAP. We used a methodology of general policy analysis and case-law study for Europe and Spain. We found a coexisting regulation in agricultural competition policy (antitrust and agricultural rules), and a heterogeneous interpretation of them. Competition rules are broadly applied in agriculture, and competition article exemptions are uncommon on the legal jurisprudence.
\end{abstract}

JEL codes: E6, E61, L4, Q18.

Keywords: competition policy, agricultural policy, CAP.

\section{Resumen}

La agricultura es un tema clave y sensible en Europa. Sin embargo, los límites entre la Política Agraria Común (PAC) y las políticas de defensa de la competencia no están bien definidos. Este artículo evalúa los límites entre la política de competencia y la PAC. La metodología analiza el marco general de políticas y el estudio particular de la jurisprudencia en Europa y España. En la regulación de la política de competencia agraria, encontramos tanto una coexistencia de las normas antimonopolio y agrícolas como una interpretación heterogénea de estas. Las normas de competencia son ampliamente aplicadas en agricultura, y las exenciones a la competencia son poco comunes en la jurisprudencia legal.

Clasificación JEL: E6, E61, L4, Q18.

Palabras clave: política de competencia, política agrícola, Política Agraria Común (PAC).

\section{Introduction}

Since the creation of the Treaty of the European Economic Community, Europe provided for the uniqueness and importance of agriculture. Similarly, in the constitution of the European Union, it was reflected the important commercial role of the Union, especially for the intra-union trade. Today, those items are collected by the new Treaty on the Functioning of the European Union (TFEU) in articles 101109 regarding competition and 38-44 TFEU articles on Agriculture and Fisheries (European Union, 2012). However, when it comes to applying the principles of competition and the concrete implementation of competition policies for agricultural products and the food industry, both -the principles of competition itself and the protection of agricultural sector- can be in conflict. 
From a legal point of view, Lamo de Espinosa Rocamora (2009) reviews the framework and the particular decisions on the matter. Carrau (2012) draws up a comparative report about national policies in Europe concerning agricultural application of EU antitrust laws. The antitrust enforcement retains only a few exceptions for the production and trade in agricultural products (Del Cont et al., 2012). However, no study on the boundaries and economics principles of the topic has been conducted so far, as far as authors have been able to identify.

Therefore, our study could be understood as a search for the boundaries of competition and protectionism in agriculture. We review the competition framework from an applied point of view, studying the practical applications in particular case studies. The review is done for Europe, and also in particular for Spain. From the evaluation of economic analysis and the elements of decision in jurisprudence, we find that demand and supply rigidities are those characteristics of agricultural markets most haven into account in the case-laws jurisprudence. Furthermore, the fragmented supply at farmer level is almost untreated, with implications in antitrust policy blanks.

The remainder of the article is structured as follows: section 2 is devoted to the methodology and develops legal framework; section 3 analyses several file-cases with the common problem of competition laws and agriculture exception compatibilities, and section 4 discusses the most remarkable features.

\section{Methodology to analyse the general competition framework}

This methodology is based on the study of the general policy framework for Europe and Spain. We start with the European policies to go down to the particular case of Spain. In Europe, competition policy for agriculture finds itself in some point between the competition rules and the common agricultural policy. We review both of them. In order to help defining the grey area (see Figure 1) that agricultural

\section{FIGURE 1}

\section{EU COMPETITION AND AGRICULTURAL POLICY FRAMEWORK}

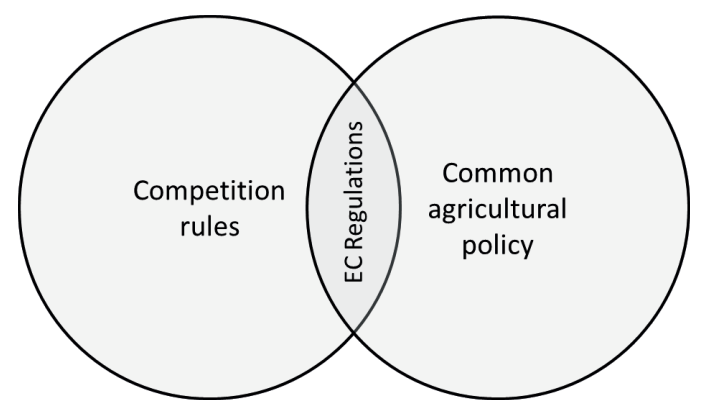

NOTE: EC stands for European Commission.

SOURCE: Own elaboration. 
competition policy is, the European Commission enacts particular regulation. Spanish framework is also analysed on the basis of national competition policy.

We go through the following laws: the competition policy framework (articles 101 to 109) from the Treaty on the Functioning of the European Union (TFEU), and the whole title III (art. 38 to 44), devoted to agriculture and fisheries. We review also the EU regulations: Council Regulation No. 1184/2006 (2006), regarding derogations from art. 101 and 102 of the TFUE, and amending acts as the Council Regulation No. 1234/2007 (2007) establishing "Common Market Organizations". The governing law for competition matters in Spain "Ley de Defensa de la Compencia" (LDC) (15/2007 Law, 3rd of July), and "Reglamento de Defensa de la Competencia" (RDC) (Real Decreto 261/2008) are reviewed.

\section{Analysis of the general competition framework}

\subsection{Europe}

In the European Union (UE), the general framework regarding competition policy are the articles 101 to 109 of the Treaty on the Functioning of the European Union (TFEU), and the Council Regulations. The article 101 declares prohibited the conducts that restrict or distort competition within the internal market ${ }^{1}$. However, article 101.3 declares as exceptions (for all the industries) any kind of agreement that contributes to improve the production or distribution, promoting the technical or economic progress. In order to apply the exceptions collected in 101.3, the agreements shall benefit consumers while not eliminating competition. Article 102 states as incompatible with the internal market any abuse of a dominant position. In conclusion, competition regulation in the TFEU do not regard particular agricultural conditions in its exceptions or general framework.

When looking for particular regulation in the Treaty on the Functioning of the European Union (TFEU), the whole title III (art. 38 to 44) is devoted to agriculture and fisheries, being the common agricultural policy (CAP) a key policy in the European Union. The particular nature of agricultural activity shall be taken into account when working out in the CAP - as considered in article 39.2-. Art. 40 states that a common organisation of agricultural markets shall be established. This common organization may include all measures required to attain the objectives of the CAP, in particular regulation of prices, aids for the production and marketing of the various products, storage and carryover arrangements, and common machinery for stabilising imports or exports (art. 40.2). The particular measures described in art. 40.2 may conflict with art. 101.1 and in particular prohibitions about: (a) fixing purchase or selling prices; (b) limit or control production, markets [...]; and (c) share markets or sources of supply.

${ }^{1}$ And, in particular those which: (a) fix purchase or selling prices; (b) limit or control production, markets [...]; (c) share markets or sources of supply; (d) apply different conditions to equivalent parties; (e) impose obligations which have no connection with the subject of the contracts. 
Boundaries amongst competition policy and common agricultural policy are not well defined. This is especially true when art. 42 specifies that competition rules shall apply to production of and trade in agricultural products, and importantly, requires the adoption of a Council Regulation for determining the applicability of competition rules to agriculture (Geradin et al., 2012). In this situation, available case-law and jurisprudence construct the limits amongst protectionism and antitrust ${ }^{2}$.

The derogations from art. 101 and 102 of the TFUE are settled through EU regulations: Council Regulation No. 1184/2006 (2006) applying certain rules of competition to the production of and trade in certain agricultural products, and amending acts as the Council Regulation No. 1234/2007 (2007) establishing a common organisation of agricultural markets and on specific provisions for certain agricultural products (Single "Common Market Organizations" - CMORegulation). Regulation 1184/2006 states that competition rules will be applied, with three exceptions ${ }^{3}$. However, these exceptions have a limited scope, and the Court of Justice have followed a strict approach with respect derogations necessary to attain the objectives of the CAP -see case COMP/C.38.279/F3 French beef (2003)- (Geradin et al., 2012). Ultimately, European Commission is who assess the applicability of the derogations case by case.

\subsection{Spain}

The governing law for competition matters in Spain is "Ley de Defensa de la Compencia" (LDC) (15/2007 Law, 3rd of July) ${ }^{4}$. The law prohibits the collusive activities, abuse of dominant position, and unfair competition actions. It does not take into account any particularity of agricultural markets. However, the agricultural derogation was gathered by the earlier law of competition of $1963^{5}$, already repealed by the later ones.

Art. 1.3 LDC is an exemption currently in force which allows all the sectors to derogate the art. 1.1 LDC case by case, but without any mention to the agricultural

\footnotetext{
${ }^{2}$ Rules on competition shall apply only to the extent determined by the European Parliament and the Council (...), account being taken of the objectives of the CAP. The Council, on a proposal from the Commission, may authorise the granting of aid: (a) for the protection of enterprises handicapped by structural or natural conditions; (b) within the framework of economic development programmes.

3 The general rules do not apply to: (1) agreements, decisions and practices that form an integral part of a national market organisation; (2) agreements, decisions and practices that are necessary in order to attain the objectives of the common agricultural policy (CAP); (3) certain agreements, decisions and practices of farmers or farmers' associations belonging to a single European Union (EU) country, provided such agreements do not introduce an obligation to charge identical prices, exclude competition or jeopardize the objectives of the CAP. (Summaries of EU Legislation, http://europa.eu/legislation_summaries/agriculture/ general framework/l24279 en.htm)

${ }^{4}$ See changes in 2013 (BOE 2013)

5 The 1963 law "Ley de represión de prácticas restrictivas de la competencia" provided inapplicability of competition rules in the agro-food sector. This law was repealed by the 1989 competition law "Ley de defensa de la competencia".
} 
markets. The art. 1.3 LDC exemption applies only when consumers equally benefit from it, and firms do not eliminate competition.

Finally, the domestic regulation "Reglamento de Defensa de la Competencia" (RDC) (Real Decreto 261/2008) derogates from certain competition rules the behaviours that entail minor market share in all the productive sectors. Regarding agriculture, any reference is made.

\section{Case studies analysis}

As explained in the general competition framework methodology, the European Commission enacts particular regulations in order to define better policy applicability for agricultural competition policy. However, this regulation is not sufficiently clear (Carrau, 2012; Del Cont et al., 2012). As consequence, jurisprudence is the guide and boundaries for these policies. In order to do it, we follow a comparative case-law study. The methodology and the search for a competition law exception is the same for the Spanish and the European cases.

We start the study of the particular competition cases in agri-food with the study of three instances with the aim of shedding some light on the applicability of the competition exceptions for agriculture. We start with a case-law on the national framework, continuing with two different ones regarding European's.

\subsection{Jerez or Sherry Wine Regulatory Board 2007, CNC Resolution 2779/07 (2009)}

This case analysis is based on a reform in the quality regulatory system of the Sherry wines in Spain. The change is introduced under the auspices of regulations of the Jerez Regulatory Board. The traditional system was the "a third law" ${ }^{6}$, a regulatory action based on finding a standardized quality for the Sherry wines. In terms of competition law, the problem is how to pass from the "a third law" to a system based on historical sales. The historical sales system has nothing to do with the quality and certainly to the offer available on each campaign, restricting all the members of the Regulatory Board. The reform is introduced as a necessity of stabilizing a contracting market, controlling the supply of each winery.

Added to this, there is an additional restriction based on the need for special authorization by the Regulatory Board when a winery wants to sell a greater amount than the own one. When this procedure is followed, the winery purchases more wine to other wholesalers-warehouses to complete its final amount. That is, the final marketed quantity is intervened without apparent relation to the quality and origin

6 "Ley del tercio", in Spanish, consists of a dynamic system of partial transfers mixing aged wines from different vintages. The Sherry aging system needs that the amount of wine in aging is about three times the volume extracted to market. With this system standardization and stabilization of the wine quality is achieved. 
required by the Regulatory Board, which justifies its existence precisely for these particular reasons.

The third important element is that regulatory changes of 2007 from the Regulatory Board are backed by a new order of the Regional Government. Therefore, public administration establishes a different competitive framework, limiting competition between wineries. The justification for this public intervention, as well as the regulatory change the Regulatory Board, is the need to stabilize the market of Jerez and Manzanilla sherry.

\subsection{French beef 2003, COMP/C.38.279/F3 (2003)}

The Commission decision relates to an agreement amongst six French federations for setting a minimum purchase price for certain categories of cattle and, then, suspends imports of beef to France. This is reflected on the competition distortions in price setting and limiting markets or production (see table 1). In this situation, the French Ministry of Agriculture backed the discussions that were taking place amongst the federations.

The assessment and decision reached by the European Commission do not consider the cattle minimum-purchase-price a measure to stabilize markets. In addition, the agreement is not needed to assure the availability of supplies; and it is no likely to ensure that supplies reach consumers at reasonable prices ${ }^{7}$. Thus, the federations are within the scope of Article 101.1 of the Treaty (former no. 81), and the agreement is not excepted from the application of it (Official Journal of the European Union, L 209, 2003).

\subsection{Spanish raw tobacco 2004, COMP/C.38.238/B.2 (2007a)}

The European Commission decision deals with a double horizontal infringement, one by processors and the other by representatives of producers of raw tobacco in Spain. The processors' infringement is based on a secret cartel which decided on fixing prices, and sharing out the quantities of each variety to be bought. This aspect of the restrictive practice has the effect of "limit or control production" and "share-out markets or sources of supply". The cartel included also a sophisticated monitoring and enforcement mechanism and mandatory transfers of tobacco. Moreover, the producers' infringement concerns agreement on the price brackets per quality grade of each raw tobacco variety that were given in the schedules annexed to the 'cultivation contracts' proposed to processors.

\footnotetext{
${ }^{7}$ In the Commission Decision published in the Official Journal of the European Union, market stabilization and security of supply are alleged by the federations as exception reason.
} 
It is worth mentioning that the legal framework and the role of the Spanish Ministry of Agriculture could engender a considerable degree of uncertainty. In fact, the jointly agreed price schedules were annexed to the 'standard' contract published in the Official Gazette (Official Journal of the European Union 2007).

We continue our review case with the addition of the early potatoes and the Scottish salmon Board cases. In those, the assessment about the role of the authorized economic committees is an issue to analyse as possible decision elements. Here, the roles of NMO (National Market Organization) and CMO (Common Market Organization) are discussed.

\subsection{Early Potatoes 1987, IV/3 1.735, OJEC L59(1988)}

The early potatoes case deals with French associations within recognized producer groups and economic committees authorized by the Ministry of Agriculture. They fix a withdrawal price and the related daily minimum price (prices are settled by the action of supply and demand). Producers are required to market their new potato crop within the markets organized in the region through the authorized economic committees. The regulation of production is also allowed.

One of the main issues of the EC decision is the assessment about the role of the authorized economic committees. In this regard, "the objectives of the national market organization are therefore similar at the national level to those pursued by the common organization at the Community level, which are set out in Article 38 (former 39) of the Treaty" (Official Journal of the European Communities 4.3.1988, pp. L 59/28). Here, the Commission considers that the provisions of the current Article 101.1 of the TFEU are declared inapplicable to the agreements reached by early potatoes French authorized economic committees.

\subsection{Scottish Salmon Board, OJEC L246(1992)}

The product object of the decision is farmed salmon, and concerns a price-fixing agreement between the Norwegian fish farmers' sales organization and the Scottish salmon farmers' association. In addition to the price-fixing issue, there was an ongoing complaint in respect of an alleged dumping in the Community of Norwegian salmon. The agreement proposed Norwegian minimum prices and Scottish minimum prices (adding a 5 or $10 \%$ premium for the Scottish). The legal assessment found that the agreement had as its object the distortion of competition in the common market. One of the elements of the negative assessment against the exemption from the application of competition rules was the national market organization. Contrary to the "early potatoes" decision, the national market organization (NMO) had no scope given the existing common market organization (CMO) for fishery products in the 
Community. Furthermore, it was "not an agreement of farmers, farmers associations or associations of such associations belonging to a single Member State". Finally, an additional element to consider was the lack of necessity for the attainment of the objectives of the CAP. (Official Journal of the European Communities L246, 1992)

In the following study-cases we would like to review two more cases (Meldoc and Sicasov) in order to further study the CAP objectives -defined in the article no. 39 TFEU- as a possible decision element.

\subsection{Meldoc 1986, OJEC L348 (1986)}

The Commission decision for the Meldoc case is settled in the Netherlands' dairy industry, in particular for liquid milk and liquid dairy products. It is worth mentioning that there is a common market organization. The market developments led to a shift of market power in favour of the demand side, causing a strong competition between the milk producers for buyers.

A semi-public body was in charge for setting the minimum prices (delegated by a Royal Decree). This minimum price was settled at the consumer level. Later on, Meldoc cartel was created, notified and approved by the Netherland authorities. A quota system was included in the approbation. But subsequently, the agreement goes further, the cartel parties would attempt to concentrate their sales in their allotted territory, and each party was obliged to protect its sales volume against outsiders. This included a series of possible countermeasures to hold down imports. The agreement also included compensations amongst suppliers due to the countermeasures adopted, as the sharing-out of the sustained losses.

The legal assessment of the Commission in the subsequent cartel is not covered as exception. It is alleged, first, that the dairy NMOs were substituted by the CMO, and second, the cartel was not needed to fulfil the CAP objectives but it was an attempt to set up a private intervention mechanism (Official Journal of the European Communities L 348).

\subsection{Sicasov 1998, OJEC L4 (1999)}

The decision regards Sicasov, an association that groups together the breeders of plant varieties protected in France. Several types of agents are involved in Sicasov: farmers using the seeds, plant breeders, the multipliers (seed producers) and multiplying farmers. The two latter are governed by a standard contract drawn up by a service approved by the Ministry of Agriculture.

It shall be mentioned that once the seed of a variety is accepted in the national catalogue, it may no longer be subject to any marketing restriction in other Member States. The breeder is free to sell the seeds. But, authorisation to reclassify is not 
granted by the breeder until four years after the entry in the common catalogue. The alleged purpose of it is preventing an adverse effect on the breeders' rights. Thus, in the legal assessment by the Commission there is a prohibition on exporting certified seeds for a period considered "not restricting competition". In addition to that, the assessment also considers that "the prohibition on exporting certified seeds contributes to improving production and distribution, and to promoting technical and economic progress" (OJEC L4, 1999). For all these reasons, competition rules are declared inapplicable to the standard agreements of Sicasov regarding the production and sale of seeds.

\section{Summing up case-law study}

As commented by Geradin et al. (2012), the agricultural competition exemption have a limited scope. Ultimately, the Commission is who assess the applicability of the derogations case by case, but the boundaries and limits between competition law and CAP remain unclear.

In spite of these legal frameworks, applicability and exceptions are a case by case study. Even when going down from the general framework to the case-law study, we did not detect a maintained decision-line in the final authority decisions. The arguments seem not to be homogeneously applied.

As a result, we can say that the regulatory framework for competition in agriculture is complex and not clearly defined. In order to look for the boundaries of agriculture protectionism and antitrust, case-by-case studies could be useful, because the caselaw defines the limits for the exemptions of competition rules.

As general comment, competition rules are broadly applied in agriculture, and competition article derogations are uncommon on the legal jurisprudence. CAP objectives shall be pursued, generally, under Common Market Organizations (CMO). Chiefly, price-fixation is prohibited as well other infringements of the competition rules.

We go down to the study of the case-laws to further delimit the reach of both frameworks: agriculture and antitrust. Table 1 summarizes the common characteristics. In general, all cases studied contain agreements on fix prices and in the most of them there are agreements on limitation of production or market access. Only in two file-cases (Early Potatoes and Sicasov) the Court has used EU Treaty agriculture articles to justify the behaviour of firms, and only in one of these there had been price fixing agreements. Besides, in four cases public institutions are involved. Even though, firms received penalties but there is no remarks related to the public behaviour. 


\section{TABLE 1}

CASE STUDIES. COMPETITION DISTORTIONS, ELEMENTS FOR THE ASSESSMENT OF THE DECISION, AND AUTHORITY'S DECISION

\begin{tabular}{|c|c|c|c|c|c|c|c|}
\hline & \multicolumn{7}{|c|}{ Case studies } \\
\hline & 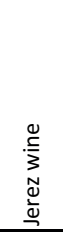 & 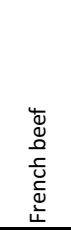 & 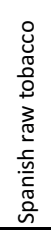 & 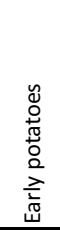 & 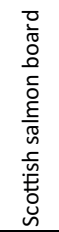 & $\frac{\frac{U}{0}}{\frac{0}{0}}$ & 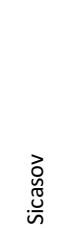 \\
\hline \multicolumn{8}{|l|}{ Competition distortions } \\
\hline \multicolumn{8}{|l|}{ Article 101.1 TFEU. Distortions of competitition: } \\
\hline a) Fixing prices & $\checkmark$ & $\checkmark$ & $\checkmark$ & $\checkmark$ & $\checkmark$ & $\checkmark$ & \\
\hline b) Limiting production, markets, tech. development, or investment & $\checkmark$ & $\checkmark$ & $\checkmark$ & $\checkmark$ & & $\checkmark$ & $\checkmark$ \\
\hline c) Share markets or sources of supply & $\checkmark$ & & $\checkmark$ & & & $\checkmark$ & \\
\hline d) Applying different conditions for parties & $\checkmark$ & & & & & $\checkmark$ & \\
\hline e) Impossing supplementary obligations not justified & $\checkmark$ & & $\checkmark$ & & & $\checkmark$ & \\
\hline \multicolumn{8}{|l|}{ Article 102 TFEU } \\
\hline \multicolumn{8}{|l|}{ Elements for the assesstment of the decision } \\
\hline Definition of $\mathrm{NMO}-\mathrm{CMO}$ & & & & $\checkmark$ & $\checkmark$ & $\checkmark(1)$ & \\
\hline \multicolumn{8}{|l|}{ Pursuit of CAP objectives (Art. 39 TFEU): } \\
\hline a) Increase of agricultural productivity & & & & $\checkmark(2)$ & & & $\checkmark(3)$ \\
\hline b) Fair standard of living of agricultural community & & & & $\checkmark(2)$ & & & \\
\hline c) Stabilizing markets & $\checkmark(1)$ & $\checkmark(1)$ & & $\checkmark(2)$ & & & \\
\hline d) Assuring availability of supplies & & & & $\checkmark(2)$ & & & $\checkmark(3)$ \\
\hline e) Ensuring that supplies reach consumers at a reasonable prices & & $\checkmark(1)$ & & $\checkmark(2)$ & & & \\
\hline Public Sector implicated on the case & $\checkmark$ & $\checkmark$ & $\checkmark$ & $\checkmark$ & & & \\
\hline \multicolumn{8}{|l|}{ Authority decision } \\
\hline European or National Authority? & Nat. & Eur. & Eur. & Eur. & Eur. & Eur. & Eur. \\
\hline Derogation of Art. 101.1 TFEU & NO & NO & NO & YES & NO & NO & YES \\
\hline
\end{tabular}

NOTE: (1) Alleged/Claimed. (2) Argued by Court. (3) Argued by Court, but not on the basis of Art. 39 TFEU. TFEU stands for Treaty on the Functioning of the European Union, NMO for National Market Organization, CMO for Common Market Organization, and CAP for Common Agricultural Policy.

SOURCE: Own elaboration.

As a result, we found an overlapping regulation in agricultural competition policy: antitrust rules and agricultural rules of the TFEU leave a great grey area. In order to shed some light, European regulation is enacted, remaining undefined as well. European Court has the final voice in interpreting and ruling a decision, so the case-law shall be studied to better understand the limits of competition and CAP. However, from the herein study of the case-laws, no concluding remarks can be done apart from the heterogeneity in the interpretation of the rules. Competition exemptions are scarce and antitrust laws are broadly applied. 


\section{References}

[1] BOE (2013). Ley 15/2007, de 3 de julio, de Defensa de la Competencia. Boletín Ofcial del Estado. Legislación Consolidada, 159.

[2] BOE (2008). Real Decreto 261/2008, Reglamento de Defensa de la Competencia. Boletín Oficial del Estado, 50.

[3] CARRAU, J. (2012). EU competition framework policy and agricultural agreements: collation and comparative analysis of significant decisions at national level. European Commission, p. 63.

[4] COMISION NACIONAL DE LA COMPETENCIA (CNC) (2010). Informe sobre competencia y sector agroalimentario,

[5] COMISIÓN NACIONAL DE LOS MERCADOS Y LA COMPETENCIA (CNMC) (2009). Resolution (Case-law 2779.07, Consejo Regulador de Denominación de Origen Vinos de Jerez y Manzanilla de Sanlúcar),

[6] DEL CONT, C.; BODIGUEL, L. and JANNARELLI, A. (2012). EU Competition Framework: Specific rules for the food chain in the new CAP.

[7] EUROPEAN COMMISSION (2007a). Commission Decision (Case COMP/C.38.238/ B.2) - Raw tobacco - Spain. Official Journal of the European Union, L 102.

[8] EUROPEAN COMMISSION (2003). Commission Decision (Case COMP/C.38.279/ F3 - French beef). Official Journal of the European Union, L 209.

[9] EUROPEAN COMMISSION (1992). Commission Decision (Case No IV/33.494 Scottish Salmon Board). Official Journal of the European Communities, L 246.

[10] EUROPEAN COMMISSION (1986). Commission Decision (IV/31.204 - MELDOC). Official Journal of the European Communities, L 348.

[11] EUROPEAN COMMISSION (1988). Commission Decision (IV/31.735 - New potatoes). Official Journal of the European Communities, L 59.

[12] EUROPEAN COMMISSION (1999). Commission Decision (IV/35.280 - Sicasov). Official Journal of the European Communities, L 4.

[13] EUROPEAN COMMISSION (2009). Competition in the food supply chain, Brussels.

[14] EUROPEAN COMMISSION (2006). Council Regulation (EC) No 1184/2006. Official Journal of the European Union, L 214.

[15] EUROPEAN COMMISSION (2007b). Council Regulation (EC) No 1234/2007. Official Journal of the European Union, L 299.

[16] EUROPEAN COMPETITION NETWORK (ECN) (2012). Report on competition law enforcement and market monitoring activities by European competition authorities in the food sector,

[17] EUROPEAN UNION (2012). Consolidated Version of the Treaty on the Functioning of the European Union. Official Journal of the European Union, C 329.

[18] GERADIN, D.; LAYNE-FARRAR, A. and PETIT, N. (2012). EU Competition Law and Economics, Oxford University Press.

[19] LAMO DE ESPINOSA ROCAMORA, P. (2009). La defensa de la competencia en la legislación de la Union Europea y en España y su aplicación en el sector agroalimentario Serie ESTU. Ministerio de Medio Ambiente y Medio Rural y Marino, ed., Madrid. 